\title{
The Effects of Customer Experience on Purchase Intention in the Shopping Centers in Jakarta
}

\author{
Anastasia Prisilla*, Pepey Riawati Kurnia \\ Sekolah Tinggi Manajemen PPM \\ Jakarta, Indonesia \\ *anastasia.prisilla@gmail.com,prk@ppm-manajemen.ac.id
}

\begin{abstract}
This study examines the factors that influence customer experience and the effect of customer experience on purchase intention using verhoef model in the 2009. The objects of this research are shopping malls in Jakarta. The background and problems of this study arise from the presence of ecommerce, which disrupts the shopping mall industry as reflected in numerous retail spaces that have been closed in recent years. Researchers have found that service interface, assortment, price, retail brand, and social environment factors have a significant positive effect on customer experience at shopping malls in Jakarta. The atmosphere factor does not have a significant positive effect on customer experience in shopping malls in Jakarta. It is suspected that there are differences in terms of respondent's profile, place, and time of respondent taking when testing the effect of atmosphere factor on the customer experience in a shopping mall. The retail brand is the factor that has the greatest influence on the customer experience in shopping malls in Jakarta. The customer experience factor has also a significant positive effect on the purchase intention in shopping malls in Jakarta.
\end{abstract}

\section{Keywords—purchase intention}

\section{INTRODUCTION}

Experience marketing is a new and interesting concept for academics and practitioners because it can help understand consumers by providing customer experience that is attractive to consumers, which serves as a guide in producing competitive product differentiation in the market [1]. Considering the aforementioned points, this study will discuss customer experience starting from its influential factors to its effects on purchase intention more thoroughly. Customer experience is one of the ways to compete by creating experiences through product creation and service provision to consumers [2].

There are various opinions on customer experience to brand experience which begin to emerge and complement one another [1]. New theories by examining holistically/thoroughly from the factors that influence customer experience to components of customer experience, especially in the retail industry [3].

Researchers found the basic use of the theory of Verhoef et al. adapted and combined with customer experience theory according to Schmitt [4]. This is because the theory of Verhoef et al. is a theory about the most recent customer experience and related to the retail industry and it associates the variable of customer experience with purchase intentions [4]. Although researchers have found several examples of journals discussing the relationship between customer experience and purchase intention, most empirical research focused more on examining the effects of customer experience on customer satisfaction and customer loyalty [5].

From this explanation, researchers have found a gap in which there is a lack of research, especially in Indonesia, which tests the theory of Verhoef et al. by studying the factors that influence customer experience simultaneously as well as examining the relationship of customer experience with purchase intention. For the object of the study, researchers chose the shopping center industry.

Selecting the shopping center industry as the research object is due to the presence of e-commerce / online business which has a significant impact on the shopping center. In an article posted on the McKinsey website, it is described that online businesses are able to provide consumers a high level of convenience with their easy access as well as to facilitate consumers in comparing specifications and prices [6]. In addition, according to an article on Bloomberg website, the closure of a number of retail shops and shopping centers happened globally [7]

This phenomenon also occurred in Indonesia in which according to a research by Jones Lang LaSalle on the Business Tribune website, the occupancy rate of shopping centers by the end of 2017 was around 89 percent or equivalent to the low occupancy rate of shopping centers which reached 31.9 hectares [8]. This lack of occupancy was due to a decrease in visits as well as consumers' product purchases [9]. However, according to Stefanus Ridwan, Chairman of Indonesia Shopping Center Association (DPP Asosiasi Pengelola Pusat Belanja Indonesia), on the CNBC Indonesia website, although online shopping has a large impact, it will not put an end to the shopping mall industry [10].

In addition, as stated by Alphonzus Widjaja, the CEO of Retail and Hospitality Sinarmasland, on the Marketeers website, experience could become the key for shopping centers to survive amidst the competition with other competitors as well as the disruption from online business [11]. This is because experience can only be found through shopping centers which have physical buildings. Experience can be created through the ambience or atmosphere and by way of the entertainment provided by the shopping centers.

The scope of the discussion of this study will be limited by several things. As the main guideline, this study will focus on proving Verhoef et al. theory in regard to the factors influencing customer experience as well as examining the 
relationship between customer experience and purchase intention [4]. Researchers will only examine the object of the research which is B-class shopping centers (middle) located in Jakarta because the most significant decline of occupancy rate came from middle-to-low shopping centers [12]. Moreover, Bclass shopping centers are a type of mall that is crowded with visitors [13]

Based on the aforementioned description, the research questions in this study are as follows:

- Is there any effect of service interface factor on customer experience in shopping centers in Jakarta?

- Is there any effect of atmosphere factor on customer experience in shopping centers in Jakarta?

- Is there any effect of assortment factor on customer experience in shopping centers in Jakarta?

- Is there any effect of price factor on customer experience in shopping centers in Jakarta?

- Is there any effect of retail brand factor on customer experience in shopping centers in Jakarta?

- Is there any effect of social environment factor on customer experience in shopping centers in Jakarta?

- Is there any effect of simultaneous service interface, atmosphere, assortment, price, retail brand, and social environment factors on customer experience in shopping centers in Jakarta?

- Is there any effect of customer experience on purchase intention in shopping centers in Jakarta?

\section{LITERATURE REVIEW AND HYPOTHESIS DEVELOPMENT}

Verhoef et al. describe the customer experience as an interaction between consumers and products, companies, or parts of the organization, which resulting in a personal reaction and is implemented in the involvement of consumers at various levels (rational, emotional, sensorial, physical, and spiritual) [14]. Gentile et al. also state that customer experience is created through pleasure, joy, satisfaction, and beauty [1]. On the other hand, Jones whose research focus on shopping describes that experience is a part of entertaining which consists of fun dan pleasurable factors [15].

There are five types of experiential marketing approaches that are often associated with strategic experimental modules which are sense, feel, think, act, and relate [16]. The components of customer experience consist of cognitive, affective, emotional, social, and physical [3]. Yang and $\mathrm{He}$ combined the results of the research by Schmitt and Verhoef et al. Customer experience component was chosen because the research results have been applied in various journals in different industries [16]. Yang and He made improvements by combining the results of these studies with the research of Verhoef et al. because this research is the most closely related to the retail industry and is the most recent research.

Thus, there are 3 (three) components of customer experience which are sensory experience, emotional experience, and social experience [4]. Sensory experience refers to the aesthetic and motoric perceptions in regard to shopping environment, atmosphere, products, and services.
Wen, measured sensory experience variable based on 4 (four) things which are arousing sensation, bringing interest, attractiveness, and being worthwhile [4,17].

Emotional experience refers to moods, emotions that are produced while going shopping. Brengman and Geuens, measure emotional experience based on 6 (six) things which are pleasure, happiness, relaxing, contentment, satisfaction, and hopefulness $[4,17]$. Social experience refers to interactions with other people or within communities. Fan and Li, measure social experience based on 4 (four) things which are finding a sense of belonging, positioning social status, promoting social status, and getting recognized [4,17].

Besides customer experience components, the factors that influence customer experience are also important. Verhoef et al. describe 5 (five) specific aspects of customer experience model as follows: social environment, service interface, retail brand, customer experience dynamic, and customer experience management strategies.

Service interface is one of the factors that influence customer experience which refers to service person, technology, and co-creation / customization [3]. Meanwhile, customer experience management strategies can be classified into several other aspects such as retail atmosphere, assortment, price, and customer experience in alternative channels. Retail atmosphere will refer to design, smell, temperature, and music in retail. Assortment will refer to the variety, uniqueness, and quality of retailers. Price will refer to the customer loyalty program and retail promotion. Customer experience in alternative channels will refer to retail which initially has 1 (one) store in an offline store, will experience the impact of shopping experience in other channels such as online stores / internet.

Retail brand will be closely related to the performance of a brand as stated in the price premium, price elasticities, market share, and expansion success [3]. The last factor is the social environment that deals with the impact of consumer interactions which affect other consumers who will later refer to reference groups, reviews, tribes, co-destruction, service personnel [3].

Besides customer experience variable, this study will also discuss purchase intention variable. There are some definitions of purchase intention in which according to Shah et al. purchase intention is part of decision making related to the reasons why consumers buy or use products for the services of a brand [18]. Purchase intention is an effective tool for predicting purchasing process [19]. According to Shen and Zhao measuring purchase intentions variable can be based on 3 (three) things which are recommending others to buy, buying for oneself, and buying for family and friends [4,17]. As stated by Schiffman and Kanuk, there are some factors which influence purchase intention [20] as follows:

- Cognitive Goal that is consumers have goals to satisfy their needs by choosing products that can be trusted without looking at economic factors based on the results of a positive evaluation of a brand.

- Emotional Goal that is consumers have goals related to emotional satisfaction such as pride and existence with the hope that using those products can improve social status. 
- Economic Goal that is consumers have goals that are rationally based on economic conditions by thinking about the advantages and disadvantages in choosing a product.

- Passive Goal that is consumers who are passive are influenced by promotions when choosing a product.

As the object of the research, shopping centers / malls are also an important aspect of this study. Malls are a shopping center that contains one or more department stores which complement small retails and restaurants with a building like a shop facing the main corridor or pedestrian that functions as a communal space from the interaction of visitors and sellers [21]. Based on the physical form, shopping centers or shopping malls are shopping facilities in the form of plazas which have access from the public roads and are equipped with areas to walk, sit, relax, and have decorative elements aiming at customer convenience [22,23].

Based on the factors such as occupancy, brands, tenancy mix, achievements and awards, facilities, building materials, and services, B-Class shopping centers are shopping malls which contain retailers who sell several international luxury brands combined with street brands such as Pull n Bear, Zara, Mango. This type of mall is a type of mall that is crowded with visitors to fulfill their daily needs [13].

In the previous research, the service interface and atmosphere factors can influence customer experience [24]. For example, a service person (service interface) who works quickly and does not keep consumers waiting or by providing music (atmosphere) in the store in order to keep customers entertained to improve customer experience. Mittchell who is an advisor from SAS'S Global Retail Industry also suggests optimizing assortment as a way to improve customer experience. Shopping centers which have wide assortment in retail stores, restaurants and entertainment stores will have great opportunities for customers to shop, eat, and continue to do their activities in the shopping centers [25].

Consumers also have a tendency to choose the highest quality goods and no longer see the products with the lowest price. They are even willing to pay more to get the highest quality products. However, for those that have fewer variations, consumers will choose the cheapest ones [26]. Consumers who are motivated to explore various stores because they are looking for variety or shopping assignments tend to stay longer in the shopping centers [25].

Researchers will also measure service interface variable in the questionnaire in accordance with the research of Hyunsik Kim \& Beomjoon Choi and Vafaeva [27]. The measurement of atmosphere variable in the questionnaire will be based on the research of Syalwani, Gurel Cetin \& Fusun Istanbullu Dincer, and Tang Wenwei and Zeng Tongtong [28]. Meanwhile, the measurement of assortment variable will be in line with the research of Ramya $J$ and Rajendran $G$. Based on the argumentation above, therefore [29]:

H1 : Service interface factor has a positive effect on customer experience in shopping centers in Jakarta.

$\mathrm{H} 2$ : Atmosphere factor has a positive effect on customer experience in shopping centers in Jakarta.
H3 : Assortment factor has a positive effect on customer experience in shopping centers in Jakarta.

The research explained the relationship of price and retail brand factors on customer experience from the identification results related to customer satisfaction, the number of shopping visits, the amount of consumer consumption, and the benefits obtained [30]. The researchers will measure the price, retail brand, and social environment variables in the questionnaire based on the research of Ramya J and Rajendran G [29]. Retail brand and social environment factors could influence customer experience [31]. Thus, the companies need to find a way to maintain their customers by creating customer experience. Based on the argumentation above, therefore:

H4 : Price factor has a positive effect on customer experience in shopping centers in Jakarta.

H5 : Retail brand factor has a positive effect on customer experience in shopping centers in Jakarta.

H6 : Social environment factor has a positive effect on customer experience in shopping centers in Jakarta.

In addition to placing customer experience as independent variable, those factors suggested by Verhoef et al. have never been examined simultaneously. Researchers found some studies who investigated 5 out of 6 factors in the theory of Verhoef et al [3]. Retail brand factor was not examined and later the study of those factors were conducted on repurchase variable [32]. The usage of Verhoef et al. theory was implemented in the research of Hyunsik Kim \& Beomjoon Choi in which 3 (three) dimensions were derived (service outcome quality, interaction quality, and peer to peer quality) [27]. Those 3 (three) dimensions resulted from 4 (four) main factors (social environment, service interface, retail store atmosphere, and past customer experience) which will be associated with Customers' Behavioral Intentions.

Ramya $\mathbf{J}$ and Rajendran $\mathrm{G}$ examined the relationship of each determinant of customer experience in various modern retail stores in India. Retail atmosphere is the most powerful factor influencing the customer experience [29]. This retail atmosphere factor was measured based on store design, temperature, music that affects the duration and the number of purchases made at retail stores.

Besides retail atmosphere, there are also price, retail brand, and social environment factors which influence customer experience significantly. On the other hand, assortment and service interface factors do not significantly influence customer experience. Assortment factor is measured based on the ability of retailers to offer their products to customers with variety, uniqueness, and quality. Service interface factor is measured based on interactions between consumers and service people and the impact of the technology used. Based on the argumentation above, therefore:

H7: Service interface, atmosphere, assortment, price, retail brand, and social environment factors simultaneously have a positive effect on customer experience in shopping centers in Jakarta.

Most empirical research focus on the discussion regarding the effect of customer experience on customer satisfaction and customer loyalty [5]. In addition, some literature state that customer experience can positively influence the purchase behavior of consumers [33]. Selecting shopping center industry 
as the object of the research was based on the problems occurred in shopping centers in Jakarta which have been described previously.

Thus, considering the journals found by the researchers which are Khan and Rahman, $\mathrm{Xu}$ and Chen, Naermoadeli et al, and Livia, researchers will discuss the relationship between customer experience and purchase intention. The measurement of customer experience and purchase intention variables in the questionnaire will be in accordance with the research conducted by Yang and He and Naermoadeli et al. Based on the argumentation above, therefore:

H8: There is an effect of customer experience on purchase intention in shopping centers in Jakarta.

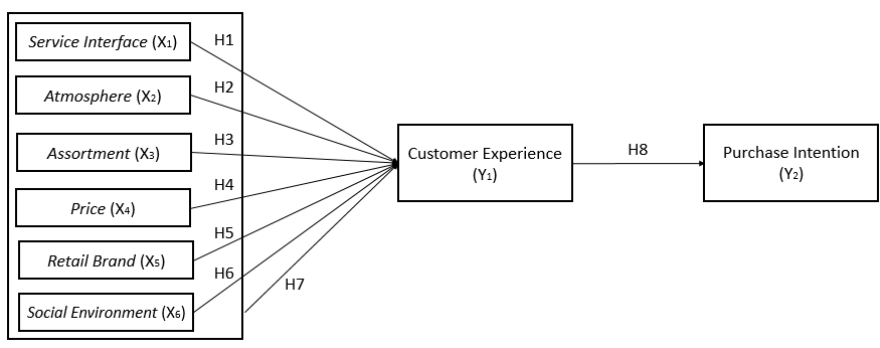

Fig. 1. Conceptual framework

The conceptual framework of the research can be seen on figure 1.

\section{RESEARCH METHODOLOGY}

This research is a descriptive study which is a part of Conclusive Research Design. More specifically, this research will use Single Cross-Sectional Design. The method that will be used by the researchers is sample survey research designs. This research will be quantitative. In this study, the researchers will use a survey method that is the structure-direct survey in which most of the questions will be fixed-alternative question in the form of a questionnaire. Furthermore, the scaling technique used by the researchers is non-comparative scales focusing on itemized rating scales mostly use Likert scale.

The questionnaire of this study will be targeted at people who reside in the Greater Jakarta Metropolitan Area (Jakarta, Bogor, Depok, Tangerang, and Bekasi) with the age group of 15-39 years old based on some points. According to Statistics Indonesia, a highly productive age group is a group of people aged 15-49 years old [34]. However, according to Indonesia Shopping Center Association, the profile of retail customers is dominated by the age group of 24-35 years old [12]

From the research conducted by Ben at all., it was found that the age group of 17-28 years old is a group that is highly associated with the malls [35]. Likewise, the age group of 2340 years old also has a correlation with the malls through utilitarian motivations [35]. Considering the population of Greater Jakarta Metropolitan Area which reach more than 6 million people, thus in accordance with Krejcie dan Morgan, the number of samples needed is 384 respondents [36]. Besides Krejcie dan Morgan, there are some general references in determining the sample which are as follows [36]:

- In most studies, the sample size is more than 30 and less than 500 .
- If the sample is divided into sub-samples (based on gender, age, occupation, etc.), the minimum sample size is 30 for each category.

- In multivariate studies (including simple regression and multiple regression), the sample size should be 10 (ten) times greater than the number of variables in the study.

- For simple experimental studies with strict experimental control, a good research has a small sample size between 10 and 20 .

After determining the respondents, the questionnaire will be spread through the methods of Electronic Interviewing and Internet Interview using Google Form. For sampling techniques, the researchers use non-probability which focuses on judgmental sampling.

This population group will be targeted to respondents who come to B-class shopping centers in Jakarta in the last 1 (one) month. The selection of the frequency of the last 1 (month) visit refers to several other sources related to shopping centers [37-39]. For the selection of the respondents will be continued with convenience sampling.

To examine the pre-test instrument, the questionnaire draft which compiled by the researchers will be spread to 30 people [40]. For the first step, the researchers will use factor analysis. Factor analysis is a technique used to reduce and summarize data. Besides being a technique for reducing and summarizing data, factor analysis is used to look at correlations between indicators and determine whether the data obtained is valid and reliable [40]. After the factor analysis, the researchers will proceed to the reliability and validity tests based on several measurements which will be explained in the sections of reliability test and validity.

After all the results data from the questionnaire are obtained, the researcher will proceed to the data analysis process. The researcher will start with the outlier's test, the classical assumption test, the reliability and validity test, until the hypothesis test using simple regression and multiple regression. For data processing, researchers will use applications of statistics which are SPSS and Excel. Outlier testing on multivariate data will be conducted using mahalanobis distance criteria [41]. Deletion of observational data will be carried out on observational data with a value of more than 15 for the amount of data above 100 [42]. The classical assumption test that will be conducted by the researchers are the multicollinearity, heteroscedasticity, normality, and linearity tests.

The reliability test is used to reveal how precise the measurements were using factor analysis with the help of SPSS software. Researchers will study based on values in the Reliability Analysis (Cronbach's Alpha). The questionnaire is thought to be reliable if the value of Cronbach's Alpha > 0.7 [43]. This validity test is used to reveal how consistent the measurements were performed (consistency). Researchers will examine based on content validity or face validity. Face Validity is divided into two things that are convergent validity (indicators of one variable gathered together) and discriminant validity (indicators of one variable gathered on one component) [40]. 
Validity test is conducted using Confirmatory Factor Analysis (CFA). Confirmatory Factor Analysis (CFA) aims to test those indicators which is a part of construct indicators of a variable [44]. This determination can be observed from the value of Kaiser Meyer-Olkin (KMO) Measure of Sampling Adequacy $\geq 0.50$ which indicates that factor analysis is adequate [40]. Meanwhile, a significant relationship between variables can be observed if the value of Bartlet's Test of Sphericity $\leq 0.05$. For the last criteria of validity, an indicator is valid forming a factor if it has factor loading of 0.60 [40]

In the regression analysis, researchers used SPSS software. Researchers will see the results displayed in the form of several tables, which are the summary model table, Anova, and Coefficients. From those three tables, the values of R-square, Anova Sig. (F-test), Constant B, Beta, and Sig (T-TEST) [45]. In the summary model table, the R-Square value is obtained which represents a large percentage of the independent variable that explains the dependent variable. Meanwhile, in the Anova table, the value of Anova Sig. (F-test) can be seen in which if the significance level is 0.0000 , it can be said that the independent variable influences the dependent variable [45]. Lastly, the values of Constant B, Beta, and Sig (T-TEST) can be obtained from the Coefficients table.

Constant B will describe the value of the dependent variable if the independent variable is considered as constant [44]. For the value of Beta, it describes that each increase of 1 (one) scale on the independent variable will cause a number of increases in the dependent variable (the amount of influence) [45]. The last is Sig (T-TEST), in which if the value of Sig (TTEST) is 0.0000 or the probability is far below 0.05 then $\mathrm{H}_{0}$ is rejected, or the regression coefficient is significant, or the independent variables really affect the dependent variables [45].

\section{RESULTS AND DISCUSSION}

This study has 420 respondents who have fulfilled 3 initial identification questions which are living in Greater Jakarta Metropolitan Area, aged 15-39 years old, and visiting B-class shopping malls in Jakarta in the past 1 (one) month. Researchers obtained respondents using the judgmental sampling method which conducted from May to June 2019. Most of the respondents are female, aged 25-29 years old, living in Jakarta, working as private employees, have an income range of IDR 5,000,000, - to IDR 10,000,000, -, have a frequency of visits to shopping centers 1 (one) - 4 (four) times in 1 (one) month, and have a frequency of purchases to shopping centers 1 (one) - 4 (four) times in 1 (one) month.

Based on the results of the questionnaire, the researchers can conclude that most respondents somewhat agree with the statements of service interface and social environment variables on the questionnaire. Meanwhile, for the statements of atmosphere, assortment, price, retail brand, customer experience, and purchase intention variables, most respondents agree.

The researcher also conducted a pre-test to 30 respondents by checking the validity and reliability of the instrument questions on the questionnaire. From the results of the factor analysis, the KMO value of these variables is greater than 0.500 so that it can be continued to the distribution of the follow-up questionnaire. For the value of Cronbach's Alpha, there are still some variables that have a value $<0.7$. However, when the researchers looked at the values of Cronbach's Alpha if Item Deleted, those variables still have a possibility to get values $>0.7$. Thus, the researchers will refine the questions on the questionnaire and will continue to distribute the questionnaire instruments that have been corrected.

Researchers will start with the outlier's test. Outliers testing will examine based on mahalanobis distance. There will be deletion of 38 observational data with a value of more than 15 (table attached). Thus, the data which will be continued in the analysis phase is 382 observational data. Although the data does not meet the number of samples according to Krejcie and Morgan, the number still meets that of samples for regression which is 10 (ten) times greater than the number of variables tested in the study [36].

After the outlier's test, the researcher would proceed to the classical assumption test. The classical assumption test conducted by researchers consists of 4 (four) tests which are multicollinearity test, heteroscedasticity test, normality test, and linearity test. The results of the multicollinearity test were carried out by observing the correlation value of the independent variables, it turned out that there were no variables that had correlations above 0.90 so that it could be concluded that there was no serious multicollinearity on the independent variables. The researcher also observed that there is no tolerance value less than 0.1 and VIF value of more than 10 . Thus, it can be concluded that there is no multicollinearity between variables in this conceptual model.

Heteroscedasticity test results are based on plot graphs by observing the predicted value of the dependent variables on the residual. On the plot graph of the dependent variables of customer experience and purchase intention, it can be seen that these points do not form regular patterns such as wavy and tend to have unclear patterns. These points are dispersed above and below the number 0 on the $\mathrm{Y}$ axis. Thus it can be concluded that there is no heteroscedasticity.

The results of the normality test are conducted by observing the histogram graph and the normal probability plot. Researchers observe the independent variables (Service Interface, Atmosphere, Assortment, Price, Retail Brand, and Social Environment) forming a histogram graph in which they form a normal distribution pattern of customer experience. In the normal probability plot, it can be seen that the data spread around the diagonal line or follow the direction of the diagonal line. Similarly, the customer experience variable on purchase intention also forms a histogram graph forming a normal distribution pattern. In the normal probability plot, it can be observed that the data spread around the diagonal line or follow the direction of the diagonal line. Based on the results of the analysis above, it can be concluded that the conceptual model meets the normality assumption.

The results of the linearity test are performed by observing the plotting on the scatter diagram. In the scatter diagram of independent variables (Service Interface, Atmosphere, Assortment, Price, Retail Brand, and Social Environment) to the customer experience, the researchers observed the data points that spread around a straight line. Thus, the independent variable has a linear relationship with customer experience. It is also the same with the scatter diagram of customer experience on the purchase intention. Researchers observed data points that spread around a straight line in which the customer experience variable also has a linear relationship to 
purchase intention. Thus, it can be concluded that the conceptual model meets the assumption of linearity and this test can proceed to regression testing.

The next step is the researcher will conduct factor analysis test followed by the reliability test by observing the value of each Cronbach's Alpha on the independent variables (Service Interface, Atmosphere, Assortment, Price, Retail Brand, and Social Environment) and the dependent variable (Customer Experience, and Purchase Intention) by determining the component of each indicator. As a result, each of those factors does not contain the same indicators and there are even similar indicators which have 2 (two) components. So researchers conduct data cleansing and produce each type of similar indicator which are on the same component. Data cleansing is performed by removing SI 1, SI 2, AS 4, P 1, P 2, RB 3, SE 4, SE 5, CE 12, PI 3, and PI 4 indicators. Thus, out of 55 (fiftyfive) indicators, researchers will use 44 (forty-four) indicators in this study.

From the results of data cleansing, every similar indicator that has been grouped and is in the same component will be tested for reliability based on the value of Cronbach's alpha. The atmosphere variable can be stated as the most reliable variable among the other independent variables. Besides the atmosphere variable, Cronbach's alpha values of retail brand and service interface variables are also greater than 0.9 , so they can also be stated as excellent reliable. Meanwhile, the price and social environment variables have a Cronbach's alpha value that is greater than 0.8 , thus the variables can also be stated as good reliable. For the assortment variable, which has a Cronbach's alpha value greater than 0.7 , the variable can also be stated as acceptable reliable. To test the reliability of the purchase intention variable that is observed in the value of Cronbach's alpha of 0.905 which is greater than 0.9 , then the variable can also be stated as excellent reliable.

In the validity test, researchers will use confirmatory factor analysis (CFA) on the independent variables (Service Interface, Atmosphere, Assortment, Price, Retail Brand, and Social Environment) and the dependent variables (Customer Experience, and Purchase Intention). From the results of the factor analysis, the Kaiser-Meyer-Olkin Measure of Sampling Adequacy value is greater than 0.50 and the significant value is 0.000 , so this factor analysis test can be continued. In addition, it can be seen from the factor loading of each indicator in every variable and has a value that is greater than 0.50 . Thus, each indicator on the independent and dependent variables is declared valid in forming a factor.

Hypothesis testing will be conducted by multiple regression analysis of the simultaneous influence of service interface, atmosphere, assortment, price, retail brand, and social environment factors on the customer experience at the shopping centers in Jakarta.

\begin{tabular}{|c|c|c|c|c|c|c|}
\hline DV & R-square & $\begin{array}{l}\text { ANOVA Sig. } \\
\text { (F-Test) }\end{array}$ & IV & B & Beta & $\begin{array}{c}\text { Sig. } \\
\text { (T-test) }\end{array}$ \\
\hline \multirow{7}{*}{ CE } & \multirow{7}{*}{0.653} & \multirow{7}{*}{$<0.001$} & Constant & 0.519 & & 0.019 \\
\hline & & & SI & 0.071 & 0.104 & 0.009 \\
\hline & & & AT & 0.010 & 0.012 & 0.751 \\
\hline & & & AS & 0.207 & 0.170 & $<0.001$ \\
\hline & & & $\mathrm{P}$ & 0.149 & 0.160 & $<0.001$ \\
\hline & & & RB & 0.342 & 0.379 & $<0.001$ \\
\hline & & & SE & 0.124 & 0.196 & $<0.001$ \\
\hline
\end{tabular}

Fig. 2. The results of regression of simultaneous service interface, atmosphere, assortment, price, retail brand, and social environment factors on customer experience.

By observing the R-square value of $0.653,65.30 \%$ of customer experience can be explained by the simultaneous service interface, atmosphere, assortment, price, retail brand, and social environment variables. While the $34.70 \%$ is explained by other causes. Anova test or $\mathrm{F}$ test result in significance level $<0.001$. Because the probability is much smaller than 0.05 , this multiple regression model can be used to predict customer experience or it can be stated that the simultaneous factors of service interface, atmosphere, assortment, price, retail brand, and social environment affect customer experience variable. To observe the effect of service interfaces, atmosphere, assortment, price, retail brand, and social environment that stand alone as variables or together (simultaneously) to the customer experience, a t-test will be conducted with the following hypothesis:

H0: Service interface factor does not have a significant positive effect on customer experience in shopping centers in Jakarta.

$\mathrm{Ha}(\mathrm{H} 1)$ : Service interface factor has a significant positive effect on customer experience in shopping centers in Jakarta.

H0: Atmosphere factor does not have a significant positive effect on customer experience in shopping centers in Jakarta.

$\mathrm{Ha}(\mathrm{H} 2)$ : Atmosphere factor has a significant positive effect on customer experience in shopping centers in Jakarta.

H0: Assortment factor does not have a significant positive effect on customer experience in shopping centers in Jakarta.

$\mathrm{Ha}(\mathrm{H} 3)$ : Assortment factor has a significant positive effect on customer experience in shopping centers in Jakarta.

H0: Price factor does not have a significant positive effect on customer experience in shopping centers in Jakarta.

Ha (H4): Price factor has a significant positive effect on customer experience in shopping centers in Jakarta.

H0: Retail brand factor does not have a significant positive effect on customer experience in shopping centers in Jakarta.

$\mathrm{Ha}$ (H5): Retail brand factor has a significant positive effect on customer experience in shopping centers in Jakarta.

H0: Social environment factor does not have a significant positive effect on customer experience in shopping centers in Jakarta.

Ha (H6): Social environment factor has a significant positive effect on customer experience in shopping centers in Jakarta.

H0: Simultaneous service interface, atmosphere, assortment, price, retail brand, and social environment factors 
do not have a significant positive effect on customer experience in shopping centers in Jakarta.

Ha (H7): Simultaneous service interface, atmosphere, assortment, price, retail brand, and social environment factors have a significant positive effect on customer experience in shopping centers in Jakarta.

Based on figure 2 of the results of regression of simultaneous service interface, atmosphere, assortment, price, retail brand, and social environment factors on customer experience, a constant value of 0.519 can be observed which states that if simultaneous service interface, atmosphere, assortment, price, retail brand and social environment are considered constant, so the average customer experience is 0.519 units. Beta value will be described as follows:

- Every increase of 1 (one) scale on the service interface variable will cause a 0.104 increase in the customer experience variable.

- Every increase of 1 (one) scale on the atmosphere variable will cause a 0.012 increase in the customer experience variable.

- Every increase of 1 (one) scale on the assortment variable will cause a 0.170 increase in the customer experience variable.

- Every increase of 1 (one) scale on the price variable will cause a 0.160 increase in the customer experience variable.

- Every increase of 1 (one) scale on the retail brand variable will cause a 0.379 increase in the customer experience variable.

- Every increase of 1 (one) scale on the social environment variable will cause a 0.196 increase in the customer experience variable.

Beta values that are positive $(+)$ indicate a positive influence. In the T-test the atmosphere factor has a value of 0.751 which is greater than the significance level of 0.050 . The factors of service interface, assortment, price, retail brand, and social environment have a significance level of 0.009 and < 0.001 which is lower than the significance level of 0.050 . Thus the regression of these variables can be stated as follows:

- For service interface factor, regression of significant variable is at 0.050 so $\mathrm{H} 0$ is rejected. Thus, the service interface factor has a significant positive effect on customer experience in shopping centers in Jakarta.

- For atmosphere factor, regression of insignificant variable is at 0.050 so $\mathrm{H} 0$ is accepted. Thus, the atmosphere factor does not have a significant positive effect on customer experience in shopping centers in Jakarta.

- For assortment factor, regression of significant variable is at 0.050 so $\mathrm{H} 0$ is rejected. Thus, the assortment factor has a significant positive effect on customer experience in shopping centers in Jakarta.

- For price factor, regression of significant variable is at 0.050 so $\mathrm{H} 0$ is rejected. Thus, the price factor has a significant positive effect on customer experience in shopping centers in Jakarta.
- For retail brand factor, regression of significant variable is at 0.050 so $\mathrm{H} 0$ is rejected. Thus, the retail brand factor has a significant positive effect on customer experience in shopping centers in Jakarta.

- For social environment factor, regression of significant variable is at 0.050 so $\mathrm{HO}$ is rejected. Thus, the social environment factor has a significant positive effect on customer experience in shopping centers in Jakarta.

- For simultaneous service interface, atmosphere assortment, price, retail brand, and social environment factors, regression of significant variable is at 0.050 based on simultaneous significance test (Statistical Test F) so $\mathrm{H} 0$ is rejected. Thus, the simultaneous service interface, atmosphere, assortment, price, retail brand, and social environment factors have a significant positive effect on customer experience in shopping centers in Jakarta.

According to figure 2 of the results of regression analysis of simultaneous service interface, atmosphere, assortment, price, retail brand, and social environment factors on customer experience, it can be observed that retail brand is a factor that gives the greatest significant effect to the increase of customer experience variable. Based on those statements, it can be concluded that the customer experience factor is affected by assortment, price, retail brand, and social environment with the mathematical equation as follows:

\section{$C E=0.519+0.071$ SI * $+0.207 \mathrm{AS} *+0.149 P *+0.342 \mathrm{RB} *+0.124 \mathrm{SE} * *$}

The equation above means:

- Regression coefficient of service interface of 0.071 states that every addition of 1 (one) unit of service interface will result in an increase of 0.071 unit in customer experience.

- Regression coefficient of assortment of 0.207 states that every addition of 1 (one) unit of assortment will result in an increase of 0.207 unit in customer experience.

- Regression coefficient of price of 0.149 states that every addition of 1 (one) unit of price will result in an increase of 0.149 unit in customer experience.

- Regression coefficient of retail brand of 0.342 states that every addition of 1 (one) unit of retail brand will result in an increase of 0.342 unit in customer experience.

- Regression coefficient of social environment of 0.124 states that every addition of 1 (one) unit of social environment will result in an increase of 0.124 unit in customer experience.

\begin{tabular}{ccccccc} 
DV & R-square & $\begin{array}{c}\text { ANOVA Sig. } \\
\text { (F-Test) }\end{array}$ & IV & B & Beta & $\begin{array}{c}\text { Sig. } \\
\text { (T-test) }\end{array}$ \\
\hline \hline \multirow{2}{*}{ CE } & \multirow{2}{*}{0.193} & \multirow{2}{*}{$<0.001$} & $\begin{array}{c}\text { Constant } \\
\text { AT }\end{array}$ & $\begin{array}{c}2.688 \\
0.358\end{array}$ & 0.439 & $<0.001$ \\
\hline
\end{tabular}

Fig. 3. The results of regression of the atmosphere factor on customer experience.

If a simple regression analysis is performed on the atmosphere factor on the customer experience factor, the results obtained are those of Anova test or the $\mathrm{F}$ test have a significance level $<0.001$. Because the probability is much 
smaller than 0.05 , this regression model can be used to predict customer experience or it can be stated that the atmosphere variable influences the customer experience variable. In the $\mathrm{T}$ test, the atmosphere factor also has a significance value $<0.001$ which is lower than the significance level of 0.050 . Thus, regression of atmosphere variable is significant with $\mathrm{H} 0$ rejected or it can be stated that the atmosphere factor has a significant positive effect on customer experience in shopping centers in Jakarta.

This study will also examine the effect of customer experience factor on purchase intention in shopping centers in Jakarta through a simple regression analysis as follows.

\begin{tabular}{ccccccc} 
DV & R-square & $\begin{array}{c}\text { ANOVA Sig. } \\
\text { (F-Test) }\end{array}$ & IV & B & Beta & $\begin{array}{c}\text { Sig. } \\
\text { (T-test) }\end{array}$ \\
\hline \hline \multirow{2}{*}{$\mathrm{PI}$} & \multirow{2}{*}{0.643} & $<0.001$ & $\begin{array}{c}\text { Constant } \\
\text { CE }\end{array}$ & $\begin{array}{c}1.170 \\
0.760\end{array}$ & 0.802 & $<0.001$ \\
\hline
\end{tabular}

Fig. 4. The results of regression of the customer experience factor on purchase intention.

By observing the R-square value of $0.643,64.30 \%$ of purchase intention can be explained by the customer experience variable. While the $35.70 \%$ is explained by other causes. Based on the results of Anova test or F test, it can be seen that the significance level $<0.001$. Because the probability is much smaller than 0.05 , this regression model can be used to predict purchase intention or it can be stated that the customer experience variable affects purchase intention variable. To observe the effect of customer experience on purchase intention, T-test will be conducted with the hypothesis as follows:

H0: Customer experience factor does not have a significant positive effect on purchase intention in shopping centers in Jakarta.

Ha (H8): Customer experience factor has a significant positive effect on purchase intention in shopping centers in Jakarta.

Based on figure 4 of the results of regression of the customer experience factor on purchase intention, a constant value of 1.170 can be observed which states that if the customer experience variable is considered constant, the average purchase intention is 1.170 . Beta values that are positive $(+)$ indicate a positive influence. In the T-test the customer experience factor a significance level $<0.001$ which is lower than the significance level of 0.050 . Thus, regression of customer experience variable is significant with $\mathrm{H} 0$ rejected. From those statements, it can be concluded that the customer experience factor has a significant positive effect on purchase intention in shopping centers in Jakarta with the mathematical equation as follows:

$$
P I=1.448+0.760 \mathrm{CE}
$$

Based on the equation above, it can be interpreted that regression coefficient of customer experience of 0.760 states that every addition of 1 (one) unit of customer experience will result in an increase of 0.760 unit in purchase intention.

Hypothesis testing in tables 1-3 is conducted based on the Sig value (T-TEST). If the value of Sig (T-TEST) is 0.0000 or the probability is far below 0.05 (the significance level is $95 \%$ ) then $\mathrm{H} 0$ is rejected, or the regression coefficient is significant, or the independent variable really affects the dependent variable [45].

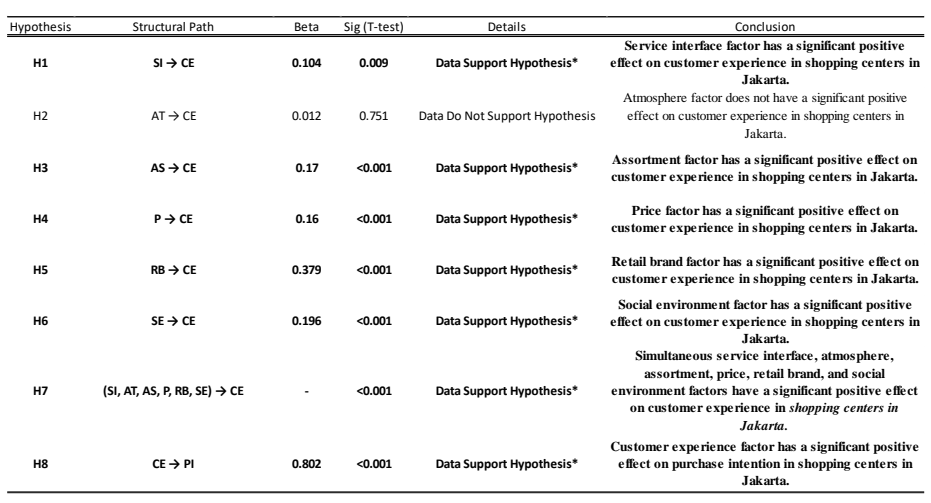

Fig. 5. The results of the testing of research hypothesis.

From the results of the regression analysis above, it can be observed that there are influences of service interface, atmosphere, assortment, price, retail brand, and social environment factors on customer experience in shopping centers in Jakarta. The service interface factor is proven to affect customer experience significantly in shopping centers in Jakarta. Every increase of 1 (one) scale on the service interface variable will cause a 0.104 increase in the customer experience variable. Respondents assessed the service interface factor based on the interactions between service person and customers as well as the use of technology through the shopping center websites [27]. Good service and interaction of the service person that are customer service also give a good effect on the customer experience in the shopping centers.

Researchers found that the atmosphere factor did not have a significant effect on the customer experience in shopping centers in Jakarta. Respondents assessed the atmosphere factor based on interior and exterior design, temperature, and music [28]. Researchers presumed that there were differences in the profile of respondents, places, and time of assigning respondents when conducting the test on the effect of the atmosphere factor on customer experience in a shopping center. The researcher also conducted a simple regression test of the atmosphere factor on customer experience. Based on the results of the simple regression test, it was proven that the atmosphere factor had a significant effect on customer experience in shopping centers in Jakarta.

Assortment factor has a significant effect on customer experience in shopping centers in Jakarta. Every increase of 1 (one) scale on the assortment variable will cause a 0.170 increase in the customer experience variable. Respondents assessed the assortment factor based on the variety, uniqueness, and quality offered by the shopping center [29]. Assortment factor becomes important for the customers in selecting products. If there are more variations offered to them, they will tend to see that those types of products have an appeal. Even customers will have a tendency to choose the highest quality goods and no longer see the products with the lowest price [26].

Price factor has a significant effect on customer experience in shopping centers in Jakarta. Every increase of 1 (one) scale on the price variable will cause a 0.160 increase in the customer experience variable. Respondents assessed the price factor based on customer loyalty programs and promotions or price reductions [29]. Customers choose the cheapest products on the ones that have fewer variations in the selection [26]. 
Retail brand factor has a significant effect on customer experience in shopping centers in Jakarta. This factor has the greatest effect. Every increase of 1 (one) scale on the retail brand variable will cause a 0.379 increase in the customer experience variable. Respondents assessed the retail brand factor based on customers' brand perceptions as indicated in the price of the product and the suitability of the price with the quality [29]. Customers tend to choose the highest quality goods. They no longer choose those with the lowest prices but the highest quality products. Customers are even willing to pay more to get the highest quality ones [26].

The last factor is social environment which is also proven to affect customer experience significantly in shopping centers in Jakarta. Every increase of 1 (one) scale on the social environment variable will cause a 0.196 increase in the customer experience variable. Respondents assessed the social environment factor based on interactions that occur to customers as measured through reference groups, reviews from other people, as well as interactions and crowds [29]. Customers have a tendency to come to the shopping center along with family, friends, or others. Good interactions can improve customer experience [3].

Researchers also examined the effect of customer experience on purchase intention in shopping centers in Jakarta. Respondents assessed the customer experience factor based on sensory experience, emotional experience, and social experience [4]. In terms of purchase intention factor, respondents assessed it in accordance with cognitive, emotional, economic, and passive goals as well as recommending and buying for oneself and others [4].

The obtained result showed that the customer experience factor significantly affected purchase intention in shopping centers in Jakarta. Every increase of 1 (one) scale on the customer experience variable will cause a 0.802 increase in the customer experience variable. This results of the study are in line with the previous research of Yang and He which stated that a good customer experience can increase the customers' purchase intention [4]. By increasing the purchase intention in shopping centers in Jakarta, the shopping centers will operate and generate good income. Customer experience has been proven to be one of the ways to compete with online disruption and to be able to increase the level of occupancy and income which have been declining so far.

\section{CONCLUSION AND SUGGESTION}

Conceptual model of Verhoef et al is a conceptual model that examines the factors that influence customer experience. Research of Yang and He discusses the effect of customer experience on purchase intention. This research was conducted using the conceptual model of Verhoef et al, followed by the conceptual model of Yang and He. Based on the information obtained by researchers in a review of previous research, the researchers conducted a study on 382 people using a questionnaire method by discussing the effect of customer experience on purchase intention in shopping centers in Jakarta. From the hypothesis and analysis results, researchers can conclude that:

- Service interface factor has a significant positive effect on customer experience in shopping centers in Jakarta.
- Atmosphere factor does not have a significant positive effect on customer experience in shopping centers in Jakarta on the simultaneous testing.

- Assortment factor has a significant positive effect on customer experience in shopping centers in Jakarta.

- Price factor has a significant positive effect on customer experience in shopping centers in Jakarta.

- Retail brand factor has a significant positive effect on customer experience in shopping centers in Jakarta.

- Social environment factor has a significant positive effect on customer experience in shopping centers in Jakarta.

- Simultaneous service interface, atmosphere, assortment, price, retail brand, and social environment factors have a significant positive effect on customer experience in shopping centers in Jakarta.

- Customer experience factor has a significant positive effect on purchase intention in shopping centers in Jakarta.

Based on the results of this study, hopefully this research can be continued and developed into a strategy for shopping centers especially in Jakarta in order to be able to compete with online disruption and increase the level of visits, occupancy, and income. Researchers hope that each factor which affects customer experience in shopping centers in as well as the customer experience factor that influences purchase intention can be developed. The development can be carried out by reexamining every indicator of each variable that can further complement the indicators of the variables in this study.

For the scientific field, researchers hope this research can contribute new information in the field of marketing management related to consumer experience, especially in the shopping center or retail industry. The researchers also hope that the results of this study can serve as a reference for further research in the field of marketing management, especially in the shopping centers in Jakarta.

The results of this study also have some limitations which later can become the guide in further research. The first limitation is that the researchers were unable to examine the entire population so that the researchers took 382 respondents with a non-probability sampling technique specifically judgmental sampling that was followed by a convenient manner as a sample of the population. Another limitation is that this study only focuses on 1 (one) city which is Jakarta so that further research assessing different cities or regions is necessary. Considering the limited time of this study, researchers have not conducted any further examination on the components which form the indicators in each variable that affects customer experience.

In further research, hopefully the testing of the conceptual model of Verhoef et al can be conducted thoroughly in the shopping center industry. Considering the possibility of a decrease in the occupancy rate and the income of shopping center occur globally, then the test of the conceptual model of Verhoef et al. can be carried out in other large cities. The further research can be started with qualitative research methods followed by quantitative methods. 
In addition, further studies also can use probability sampling techniques that can minimize the convenience factor and geographically represent. Researchers hope that there will be a comprehensive examination of indicators on each variable, especially on the atmosphere factor. The atmosphere factor is not only limited to the design of buildings both interior and exterior, temperature, smell, and music, but also the other forming elements of each indicator.

In this study, there are various findings that can provide support and empirical evidence for the literature review that has been described as follows:

- This study proves the approach of Verhoef et al. through a questionnaire. Indicator of questions on the questionnaire used references from other journals that are adapted to the places of research which are Jakarta, Bogor, Depok, Tangerang, and Bekasi. Customer experience is assessed at various levels (rational, emotional, sensorial, physical, and spiritual). However, Verhoef et al., did not discuss more specifically that the customer experience can be created through happiness, joy, satisfaction, and beauty. The indicators of happiness, joy, satisfaction, and beauty were used by the researchers to examine the level of variables in this study.

- Similarly, in the research of Yang and He, the purchase intention factor was explained by 3 indicators which were recommending others to buy, buying for oneself, and buying for family and friends. But the researchers also added other indicators that were cognitive, emotional, economic, and passive goals.

In addition, this research is also expected to provide benefits to related parties as follows:

- For property companies, developers, or shopping center development companies, they are expected to be able to develop the results of this research into a strategy to increase customer experience and purchase intention from the customers based on the most important factors for them

- For the academics, hopefully the results of this research can improve and complement the information related to shopping centers or retails in Jakarta.

\section{REFERENCES}

[1] B. Schmitt, "Experience marketing: Concepts, frameworks and consumer insights," Foundations and Trends $₫$ in Marketing, vol. 5, no. 2, pp. 55-112, 2011.

[2] B.J. Pine and J. Gilmore, The Experience Economy: Work is Theatre and Every Business a Stage. Cambridge, MA: Harvard Business School Press, 1999.

[3] P.C. Verhoef, K.N. Lemon, A. Parasuraman, A. Roggeveen, M. Tsiros, and L.A. Schlesinger, "Customer Experience Creation: Determinants, Dynamics and Management Strategies,” Journal of Retailing, 2009.

[4] Z.Y. Yang and L.Y. He, "Goal, customer experience and purchase intention in a retail context in China: An empirical study," African Journal of Business Management, 2011.

[5] J.J. Brakus, B.H. Schmitt and L. Zarantonello, "Brand Experience: What is it? How is it measured? Does it affect loyalty?" Journal of Marketing, 2009 .
[6] Fantoni, Roberto, Hoefel, Fernanda, and M. Mazzarolo, "The Future of the Shopping Mall, McKinsey," [online]. Retrieved from https://www.mckinsey.com/business-functions/marketing-and-sales/ourinsights/the-future-of-the-shopping-mall

[7] N. Buhayar and L. Coleman-Lochner, "Retail Store Closures in U.S. Set for Record. Bloomberg Businessweek," [Online]. Retrieved from https://www.bloomberg.com/news/articles/2018-04-17/retail-storeclosures-in-u-s-set-for-record

[8] F. Anjungroso, "Luas Pusat Perbelanjaan di Jakarta yang Kosong Capai 31,9 Hektare," Tribun Bisnis, [Online]. Retrieved from http://www.tribunnews.com/bisnis/2018/02/19/luas-pusat-perbelanjaandi-jakarta-yang-kosong-capai-319-hektare

[9] E. Hutapea, “Orientasi Pengunjung Berubah, Tingkat Hunian Mal Turun," [Online]. Retrieved from https://properti.kompas.com/read/2019/02/15/173855121/orientasipengunjung-berubah-tingkat-hunian-mal-turun

[10] L. Hasibuan, “APPBI: Tak Semua Toko Konvensional Tutup Karena Online. CNBC Indonesia," [Online]. Retrieved from https://www.cnbcindonesia.com/fintech/20180413093820-3710843/appbi-tak-semua-toko-konvensional-tutup-karena-online

[11] S. Bachdar, "Mengapa Experience Begitu Penting bagi Pusat Belanja? Marketeers," [Online]. Retrieved from http://marketeers.com/mengapaexperience-begitu-penting-bagi-pusat-belanja/

[12] T. Bosnia, "Banyak Toko Tutup, Tingkat Keterisian Mal Turun Cuma 81,2\%," [Online]. Retrieved from https://www.cnbcindonesia.com/news/20180614152313-419199/banyak-toko-tutup-tingkat-keterisian-mal-turun-cuma-812

[13] Propsocial, "Classifications of Shopping Malls," [Online]. Retrieved from https://www.propsocial.my/topic/300/classifications-of-shoppingmalls-posted-by-propsocial-editor

[14] C. Gentile, N. Spiller, and G. Noci, "How to sustain the customer experience: An overview of experience components that co-create value with the customer," European Management Journal, 2007.

[15] V. Popa and M. Barna, Customer and Shopper Experience Managament Romania: Valahia University of Targoviste, 2013.

[16] B. Schmitt, Experiential Marketing: How to Get Customers to Sense, Feel, Think, Act, Relate to Your Company and Brands. New York: The Free Press, 1999.

[17] A. Nasermoadeli, K.C. Ling, and F. Maghnati, "Evaluating the Impact of Customer Experience on Purchase Intention," International Journal of Business and Management, 2013.

[18] V. Mirabi, H. Akbariyeh, and H. Tahmasebifard, "A Study of Factor Affecting on Customers Purchase Intention. Case Study: the Agencies of Bono Brand Tile in Tehran," Journal of Multidisciplinary Engineering Science and Technology (JMEST), 2015.

[19] A. Ghosh, Retail management. Chicago: Drydden Press, 1990.

[20] Livia, Analisa Pengaruh Customer Experience Terhadap Minat Beli Konsumen Di Sushi Tei Restaurant Surabaya. Surabaya: Universitas Kristen Petra, 2014.

[21] E. Marlina, Panduan Perancangan Bangunan Komersial. Yogyakarta: Andi Offset, 2008

[22] F. Gibbert, Town Design. London: The Architectural Press, 1959.

[23] E.E. Adrianto, Pusat Perbelanjaan di Yogyakarya. Yogyakarta: Universitas Atma Jaya Yogyakarta, 2013.

[24] J. Baker, "The Influence of Multiple Store Environment Cues on Perceived Merchandise Value and Patronage Intentions," Journal of Marketing, 2002.

[25] M.H.A. Gafar, N.A.M. Ali, and F.N. Abdullah, "Determinats of Customer Experience Creation in Retail Industry," Internatioal Journal of Business, Economics, and Law, vol 13, 2017.

[26] Bertini, Marco, Wathieu, Luc, and S.S. Iyengar, "The Discriminating Customer : Product Proliferation and Willingness to Pay for Quality," Journal of Marketing Research American Marketing Association, 2012.

[27] H. Kim and B. Choi, "The Influence of Customer Experience Quality on Customers' Behavioral Intentions," Service Marketing Quartely Routledge Taylor \& Francis Group, 2013.

[28] W. Tang and T. Zeng, "An Empirical Research on Influencing Factors of Customer Experience of Retail Industry Aiming to Improve Custome Satisfaction: Taking Supermarket as an Example," Proceedings of the 7th International Conference on Innovation \& Management, 2010. 
[29] J. Ramya and G. Rajendran, "The Determinants of Customer Experience - a Comparative Study," European Journal of Economics, Finance and Administrative Sciences, 2013.

[30] B. Kamaladevi, "Customer Experience Management in Retailing," The Romanian Economic Journal, 2009.

[31] E. Andajani, "Customer Experience Model: Social Environment, Retail Brand and Positive WOM," Macrothink Institute Research in Business and Management, 2014.

[32] M. Alvi, Analisis Pengaruh Customer Experience Terhadap Minat Beli Ulang Pada Taman Kuring Palem Resto \& Cafe. Padang: Universitas Andalas, 2018.

[33] B.J.W.D. Babin and M. Griffin, "Work and/or fun: Measuring hedonic and utilitarian shopping value," Journal of Consumer Research, 1994

[34] Katadata, "Berapa Jumlah Wanita Usia Produktif di Indonesia," [Online]. Retrieved from https://databoks.katadata.co.id/datapublish/2017/04/21/berapa-jumlahwanita-usia-produktif-di-indonesia.

[35] T.W. Natalia and H.E. Kusuma, "Hubungan antara Motivasi Belanja dan Preferensi Shopping Mall di Kota Bandung," Temu Ilmiah IPLBI 2014, 2014.

[36] U. Sekaran and R. Bougie, Research Methods for Business. United Kingdom: John Wiley \& Son Ltd, 2016.
[37] S.W. Sukmasari, Analisis Perilaku Pria dalam Berbelanja di Shopping Mall Yogyakarta. Yogyakarta: Universitas Sanata Dharma, 2010.

[38] R.D. Santy, Pembelian Impulsif Ditinjau dari Faktor Kepribadian Konsumen dengan Menggunakan Trait The Big Five Personality (Survey pada Pengunjung Mall di Kota Bandung). Bandung: Universitas Komputer Indonesia Bandung, 2018.

[39] H. Nilam, Analisis Pengaruh Karakteristik Individu dan Karakteristik Ritel terhdap Frekuensi Belanja di Surabaya. Surabaya: Universitas Katolik Widya Mandala, 2012.

[40] N.K. Malhotra, Marketing Research : an Applied Orientation Global Edition. New Jersey: Pearson Education, Inc., 2010.

[41] Ferdinand, Metode Penelitian Manajemen: Pedoman penelitian untuk Skripsi, Tesis, dan Desertasi Ilmu Manajemen. Semarang: Badan Penerbit Universitas Diponegoro, 2002.

[42] V. Barnett and T. Lewis, Outliers in Statistical Data. California: John Wiley \& Son, 1978.

[43] B. Sharma, "A Focus on Reliability in Developmental Research through Cronbach's Alpha among Medical, Dental, amd Paramedical Professionals," Asian Pacific Journal of Health Science, 2016.

[44] I. Ghozali, Aplikasi Analisis Multivariate Dengan Program SPSS. Semarang: Badan Penerbit Universitas Diponegoro, 2011.

[45] S. Santoso, SPSS (Statistical Product and Service Solutions). Jakarta: PT Elex Media Komputindo, 2000. 